\title{
EVALUATION OF PHYSIOLOGICAL PARAMETERS IN PAPAYA GENOTYPES UNDER MIDDLE GUJARAT CONDITIONS
}

\section{P. N. KORE, M. J. PATEL, R. P. VASARA, LOKESH YADAV \& SUMIT SINGH}

Department of Horticulture, B. A. C. A. Anand Agricultural University, Anand, Gujarat, India

Twelve genotypes, was evaluated for morphological and yield parameters under middle Gujarat during the year 2015 and 2016. Results revealed from the pooled base that the highest plant height and maximum leaf area was measured in genotype $V_{5}\left(C O\right.$ 8). Maximum stem girth and no. of leaves per plant were recorded by genotype $V_{11}(G A P 30)$ while, petiole length was recorded with $V_{6}(G A P$ 6). The significantly minimum days taken to first flower initiation, PLW and maximum shelf life were observed in genotype $V_{4}$ (Madhu Bindu). Minimum plant height at first flower from ground level, days taken from anthesis to maturity, maximum total number of fruits per plant were measured in $V_{1}(P u s a N$ Nana). The significantly maximum number of marketable fruits per plant was observed in genotype $V_{2}$ (Pusa Dwarf) while, average weight of marketable fruits, fruit yield per plant, yield per hectare, volume of fruit, length of fruit and diameter of fruit were recorded in genotype $V_{10}(G A P 29)$.
\end{abstract}

KEYWORDS: Papaya, Genotype, Physiological Parameters

Received: Aug 07, 2017; Accepted: Aug 27, 2017; Published: Dec 15, 2017; Paper Id.: IJASRDEC201756

\section{INTRODUCTION}

Presently, papaya cultivation is spread over tropical and sub-tropical part of the world covering $32^{\circ} \mathrm{N}$ and $32^{0} \mathrm{~S}$ on the globe. Top twenty papaya cultivating countries are distributed in Asia (India, Bangladesh, Thailand, Indonesia, Philippines, Malaysia and China), Africa (Nigeria, Ethiopia, Congo, Kenya, Ivory Coast and Mozambique), Latin and Central America (Brazil, Mexico, Venezuela, El Salvador, Colombia and Cuba). Some developed countries like USA (Hawaii), Australia, South Africa and Taiwan also cultivate papaya, have higher productivity of better quality fruits, but they have very small area of cultivation. India is supposed to be the largest producer of papaya in the world. In India, it is cultivated an estimated area of 133.4 thousand ha with 5639.3 thousand MT production (Anon., 2015) and the productivity of the fruit is $42.3 \mathrm{MT} / \mathrm{ha}$. In Gujarat state, it is cultivated an estimated area 19.59 thousand hectares with 1185.47 thousand MT production (Anon., 2015). Anand, Surat, Vadodara, Kachchh, Junagadh, Jamnagar, Mehsana, Bharuch, Kheda, Ahmedabad and Banaskantha are the important papaya growing districts of Gujarat.

There is wide diversity of biological types of cultivated papaya, which may be dioecious, monocious or hermaphrodite (Arriola et al., 1980). The vegetative, reproductive and quality responses of crop genotypes are influenced by agro climatic conditions of particular region. Furthermore, morphological characters have been used to characterize accessions and define the structure of genotypes collection.

Being a short duration crop papaya is famous under middle Gujarat farmers but, due to some problems to procure seeds of improved varieties of papaya for commercial cultivation, the present investigation is planned with 
an objective evaluation of recently released varieties from public and private institutes with respect to reproductive parameters under middle Gujarat conditions.

\section{MATERIAL AND METHODS}

Experiment conducted on "Evaluation of physiological parameters in papaya genotypes under middle Gujarat conditions" was carried out during 2015 and 2016 at Horticultural Research Farm, Anand Agricultural University, Anand with different 12 genotypes viz., Pusa Nanha, Pusa Dwarf, Pune Selection 3, Madhu Bindu, CO 8, GAP 6, GAP 7, GAP 10, GAP 12, GAP 29, GAP 30 and GAP 31 of papaya (Carica papaya L.). One genotype was considered as a treatment and each treatment was replicated three times. Five plants were randomly selected for recording the observations. The experiment was laid out in Randomized Block Design. Physical parameters were recorded from the selected plants and after harvesting fruit yield parameters were recorded. The Statistical analysis was followed from the procedure which is given by Panse and Sukhatme (1985).

\section{RESULTS AND DISCUSSIONS}

Growth and development of papaya was significantly influenced by different genotypes. Pooled analysis given for morphological and flowering characters of papaya in Table 1.

Table 1: Effect of Different Papaya Genotypes on Morphological and Flowering Parameters (Pooled Data)

\begin{tabular}{|c|c|c|c|c|c|c|c|c|c|}
\hline $\begin{array}{l}\text { Tr. } \\
\text { No. }\end{array}$ & Genotypes & $\begin{array}{c}\text { Plant } \\
\text { Height }(\mathbf{c m})\end{array}$ & $\begin{array}{l}\text { Stem Girth } \\
\quad(\mathrm{cm})\end{array}$ & $\begin{array}{l}\text { No. of } \\
\text { Leaves } \\
\text { Plant }^{1}\end{array}$ & $\begin{array}{c}\text { Petiole } \\
\text { length }(\mathrm{cm})\end{array}$ & $\begin{array}{c}\text { Leaf } \\
\text { Area }\left(\mathrm{cm}^{2}\right)\end{array}$ & $\begin{array}{l}\text { Days Taken to First } \\
\text { Flower Initiation } \\
\text { (Days) }\end{array}$ & $\begin{array}{l}\text { Plant Height (cm) at } \\
\text { First Flower from } \\
\text { Ground Level }\end{array}$ & $\begin{array}{c}\text { Days Taken from } \\
\text { Anthesis to } \\
\text { Maturity }\end{array}$ \\
\hline $\mathrm{V}_{1}$ & PusaNanha & 91.17 & 12.22 & 19.67 & 31.44 & 205.23 & 188.28 & 43.39 & 106.50 \\
\hline $\mathrm{V}_{2}$ & PusaDwarf & 98.39 & 11.94 & 21.39 & 33.44 & 205.22 & 186.39 & 46.00 & 107.83 \\
\hline $\mathrm{V}_{3}$ & Pune Selection 3 & 111.56 & 11.81 & 18.06 & 31.67 & 552.02 & 196.78 & 51.83 & 128.39 \\
\hline $\mathbf{V}_{4}$ & MadhuBindu & 120.50 & 12.03 & 16.83 & 31.72 & 184.78 & 166.83 & 65.83 & 125.78 \\
\hline $\mathbf{V}_{5}$ & $\cos 8$ & 159.89 & 15.78 & 17.39 & 33.89 & 960.82 & 197.61 & 60.33 & 136.39 \\
\hline $\mathrm{V}_{6}$ & GAP 6 & 105.22 & 16.50 & 21.81 & 36.56 & 255.40 & 197.00 & 58.39 & 138.72 \\
\hline $\mathrm{V}_{7}$ & GAP 7 & 111.17 & 16.67 & 24.17 & 32.28 & 559.38 & 195.22 & 59.17 & 113.33 \\
\hline $\mathrm{V}_{8}$ & GAP 10 & 121.17 & 16.81 & 23.96 & 30.01 & 199.60 & 188.89 & 74.67 & 129.39 \\
\hline $\mathbf{V}_{9}$ & GAP 12 & 148.61 & 16.69 & 26.57 & 28.72 & 121.42 & 192.11 & 72.33 & 136.39 \\
\hline $\mathrm{V}_{10}$ & GAP 29 & 147.89 & 17.83 & 23.83 & 31.61 & 490.37 & 200.89 & 81.56 & 141.00 \\
\hline $\mathbf{v}_{11}$ & GAP 30 & 140.50 & 21.28 & 26.58 & 31.11 & 330.22 & 208.17 & 88.33 & 155.50 \\
\hline $\mathrm{V}_{12}$ & GAP 31 & 144.94 & 19.89 & 26.22 & 33.78 & 232.31 & 201.50 & 72.61 & 153.33 \\
\hline \multirow{2}{*}{$\mathrm{T}$} & $\mathbf{S . E m} \pm$ & 2.84 & 0.61 & 0.68 & 0.81 & 14.76 & 4.90 & 2.13 & 1.67 \\
\hline & C.D. $(P=0.05)$ & 8.06 & 1.74 & 1.93 & 2.30 & 41.84 & 15.25 & 6.04 & 4.77 \\
\hline \multirow{2}{*}{$\mathrm{Y} \times \mathrm{T}$} & S.Em \pm & 4.48 & 0.88 & 1.02 & 1.27 & 19.54 & 1.49 & 3.36 & 2.37 \\
\hline & C. D. $(P=0.05)$ & NS & NS & NS & NS & NS & 4.25 & NS & NS \\
\hline & C.V. $\%$ & 6.20 & 9.66 & 7.95 & 6.85 & 9.45 & 1.33 & 9.03 & 3.13 \\
\hline
\end{tabular}

The maximum plant height $(159.89 \mathrm{~cm})$ and leaf area $\left(960.82 \mathrm{~cm}^{2}\right)$ were recorded by genotype $\mathrm{V}_{5}(\mathrm{CO} 8)$. The maximum stem girth $\left(21.28 \mathrm{~cm}\right.$ ) and number of leaves per plant (26.58) were recorded by genotype $\mathrm{V}_{11}$ (GAP 30) while, maximum petiole length $(36.56 \mathrm{~cm})$ was recorded with $\mathrm{V}_{6}(\mathrm{GAP}$ 6). Morphological parameters viz., plant height, stem girth, number of leaves per plant, petiole length and leaf area at the time of first flowering were found significant among the papaya genotypes. This is due to different genetic constitution of papaya genotypes for morphological parameters and different inherent nature and exposure of response to climatic factors. These results are in accordance with the findings of Kamalkumar et al. (2007), Saran (2010), Davamani et al. (2013) and Emede et al. (2016).

The minimum days taken to first flower initiation (166.83 days) was found significant with $\mathrm{V}_{4}$ (Madhu Bindu). Significantly minimum plant height at first flower from ground level $(43.39 \mathrm{~cm})$ and days taken from a thesis to maturity (106.50 days) was observed in genotype $V_{1}$ (Pusa Nanha). 
It is evident from the data that the different genotypes recorded significant differences among the genotypes for a flowering behaviour of papaya. The flowering and fruiting habit of papaya genotypes were highly varies as it is highly cross pollinated crop. Flowering behaviour differences in genotypes might be due to different genetic makeup and inherent characters of individual genotype and also high influence of environment. High temperature accompanied by dry conditions adversely affect flowering and fruit set of papaya (Saran et al. 2016). Data related to temperature is mentioned in appendix-II. These results are in line with the findings of Ghanta and Mondal (1992), Dinesh et al. (2000), Jambhale et al. (2014), Saran et al. (2015), and Chalak et al. (2016).

Moreover, yield performance of any genotype is deemed as a progressive effect of yield attributes. These results are in agreement with findings of Dinesh et al. (2000), Singh et al. (2005), Saran (2010), Meena et al. (2012), Ara et al. (2013), Das and Dinesh (2013), Saran et al. (2015), Chalak et al.(2016) and Emede et al. (2016).

Thus, varieties GAP 29, Pusa Nanha and Pusa Dwarf were found more convenient for yield attributing parameters while, GAP 6, GAP 30 and CO 8 were better for morphological and flowering characters.

Table 2: Effect of Different Papaya Genotypes on Yield Attributing Parameters (Pooled Data)

\begin{tabular}{|c|c|c|c|c|c|c|c|c|c|}
\hline $\begin{array}{l}\text { Tr. } \\
\text { No. }\end{array}$ & Genotypes & $\begin{array}{l}\text { Total Number of } \\
\text { Fruits Plant }^{-1}\end{array}$ & $\begin{array}{c}\text { Number of } \\
\text { Marketable } \\
\text { Fruits Plant }^{-1}\end{array}$ & $\begin{array}{c}\text { Average } \\
\text { Weight of } \\
\text { Marketable } \\
\text { Fruit (g) }\end{array}$ & $\begin{array}{l}\text { Fruit Yield } \\
\text { (kg Plant }^{-1} \text { ) }\end{array}$ & $\begin{array}{l}\text { Fruit } \\
\text { Yield q ha-1 }\end{array}$ & $\begin{array}{l}\text { Average } \\
\text { Volume of } \\
\text { Fruit (cc) }\end{array}$ & $\begin{array}{c}\text { Fruit } \\
\text { Length } \\
(\mathbf{c m})\end{array}$ & $\begin{array}{c}\text { Fruit } \\
\text { Diameter } \\
\text { (cm) }\end{array}$ \\
\hline $\mathbf{V}_{1}$ & PusaNanha & 42.39 & 30.53 & 673.13 & 21.34 & 307.29 & 505.50 & 18.18 & 10.81 \\
\hline $\mathbf{v}_{2}$ & PusaDwarf & 40.53 & 31.86 & 646.01 & 21.88 & 315.04 & 484.06 & 17.98 & 10.56 \\
\hline$V_{3}$ & Pune Selection 3 & 20.96 & 12.94 & 597.57 & 11.85 & 170.66 & 459.61 & 16.19 & 11.69 \\
\hline $\mathbf{v}_{4}$ & MadhuBindu & 30.13 & 25.33 & 761.17 & 22.17 & 319.18 & 504.72 & 16.68 & 10.16 \\
\hline$V_{5}$ & $\mathrm{CO} 8$ & 25.39 & 17.19 & 811.79 & 15.80 & 227.58 & 462.78 & 20.70 & 10.47 \\
\hline $\mathbf{V}_{6}$ & GAP 6 & 24.19 & 15.33 & 786.11 & 13.36 & 192.45 & 762.78 & 18.58 & 11.33 \\
\hline$V_{7}$ & GAP 7 & 24.92 & 16.31 & 996.14 & 18.63 & 298.09 & 933.33 & 16.89 & 12.74 \\
\hline $\mathbf{V}_{8}$ & GAP 10 & 24.53 & 18.19 & 989.50 & 21.05 & 303.06 & 452.78 & 18.85 & 13.68 \\
\hline $\mathrm{V}_{0}$ & GAP 12 & 23.11 & 14.14 & 1043.25 & 16.91 & 270.56 & 800.56 & 18.81 & 13.66 \\
\hline $\mathbf{V}_{10}$ & GAP 29 & 26.75 & 17.00 & 1132.71 & 26.08 & 417.26 & 988.33 & 23.87 & 14.16 \\
\hline $\mathbf{v}_{11}$ & GAP 30 & 25.14 & 15.39 & 945.28 & 15.63 & 250.09 & 416.83 & 15.47 & 10.12 \\
\hline $\mathbf{v}_{12}$ & GAP 31 & 32.64 & 24.89 & 928.97 & 25.90 & 414.37 & 530.83 & 15.69 & 10.26 \\
\hline \multirow[b]{2}{*}{$\mathrm{T}$} & \begin{tabular}{l|l} 
& S.Em \pm \\
\cline { 2 - 2 }
\end{tabular} & 3.91 & 2.35 & 24.24 & 1.83 & 26.86 & 20.87 & 0.38 & 0.33 \\
\hline & $\begin{array}{l}\text { C.D. (P } \\
=0.05)\end{array}$ & 12.18 & 7.32 & 69.08 & 5.69 & 83.59 & 59.48 & 1.09 & 0.93 \\
\hline \multirow[b]{2}{*}{$\mathrm{Y} \times \mathrm{T}$} & S.Em \pm & 1.49 & 1.37 & 24.28 & 1.09 & 16.63 & 29.51 & 0.61 & 0.51 \\
\hline & $\begin{array}{l}\begin{array}{l}\text { C. D. (P } \\
=0.05)\end{array} \\
\text { (1) }\end{array}$ & 4.26 & 3.89 & NS & 3.10 & 47.39 & NS & NS & NS \\
\hline \multicolumn{2}{|r|}{ C.V. \% } & 9.20 & 11.42 & 6.90 & 9.79 & 9.92 & 8.40 & 5.77 & 7.64 \\
\hline
\end{tabular}

\section{REFERENCES}

1. Ara, N., Hossain, M. F. and Kaiser, M. O. (2013). Comparative performance of fifteen papaya genotypes. Bull. Inst. Trop. Agr., Kyushu Univ.36: 71-78.

2. Badillo, V. M. (2001). Nota correctivaVasconcellast. Hilly no VasconcellaCaricaceae. Ernstia11: 75-76.

3. Chalak, S. U., Kamble, A. B. and Bhalekar, S. G. (2016). Evaluation of different papaya cultivars for yield, quality and papaya ring spot disease under Pune conditions. J. KrishiVigyan5(1): 60-63.

4. V. Manju \& S. Kumar, Seed Leachate Conductivity and its Correlation with the Seed Viability and Germination TNAU Papaya Cv. CO8 Seeds Stored under Different Environmental Conditions, International Journal of Agricultural Science and Research (IJASR), Volume 5, Issue 1, July - August 2015, pp. 127-130

5. Das, S. C. and Dinesh, M. R. (2013). Evaluation of varieties and hybrids for physico-chemical characters in papaya (Carica papaya L.). J. Hortl. Sci.8(2): 234-235.

6. Davamani, J., Balamohan, T. N. and Sudha, R. (2013). Evaluation of papaya (Carica papaya L.) hybrids for yield and papain 
recovery. J. Hortl. Sci.8(2): 165-171.

7. Dinesh, M. R.; Reddy, B. M. C. and Reena, N. A. (2000). Varietal improvement of papaya (Carica papaya L.). J. of Applied Hort.2(2): 121-123.

8. Emede, T. O., Ajayo, B. S. and Eduep, I. P. (2016). Performance, character correlation and nutritional composition of papaya (Carica papaya L.) lines in Edo state of Nigeria. Acta Hort. 1111: 99-104.

9. Gavhane. M. S,Desale. R. J \& Ghule B. K, Studies on Effect of Chemical and Sensory Aspect of Papaya Lassi, International Journal of Agricultural Science and Research (IJASR), Volume 5, Issue 3, May - June 2015, pp. 55-60

10. Ghanta, P. K. and Mondal, S. K. (1992). Genotypic variability and correlation coefficients relating to fruit yield and a few other quantitative characters in papaya (Carica papaya L.) cultivars. South Indian Hort.40 (5): 242-247.

11. Jambhale, V. M., Kute, N. S. and Pawar, S. V. (2014). Studies on genetic variability parameters. Character association and path analysis among yield and yield contributing traits in papaya (Carica papaya L.). The Bioscan9(4): 1711-1715.

12. Kamalkumar, R.; Soorianathasundaram, K. and Arunkumar, R. (2007). Morphogenicperformance of indigenous dioecious papaya hybrids under tropical condition of India. South Indian Hort., 55(1-6) 110-116.

13. Kim, M. S., Moore, P. H. and Zee, F. (2002). Genetic and molecular characterization of Carica papaya L. Genomes 45: 503512.

14. Meena, B. S.; Varma, L. R. and Mehta, R. S. (2012). Evaluation of papaya varieties under North Gujarat conditions. Indian J. Hort. 69(1): 114-116.

15. Panse, V. G. and Sukhatme, P. V. 1985. Statistical methods for agricultural workers, ICAR, New Delhi, $4^{\text {th }}$ Edn.

16. Saran, P. L. and Choudhary, R. (2013). Drug bioavailability and traditional medicaments of commercially available papayaa review. African J. Agric. Res.8(25): 3216-3223.

17. Saran, P. L., Choudhary, R., Solanki, I. S., Patil, P. and Kumar, S. (2015). Genetic variability and relationship studies in new Indian papaya (Carica papaya L.) germplasm using morphological and molecular markers. Turkish J. Agric. and Forestry 39: 310-321.

18. Saran, P. L. (2010). Screening of papaya cultivars under Doon valley conditions. PantnagarJ. Res.8(2): 246-247.

19. Singh, D. K.; Paul, P. K. and Ghos, S. K. (2005). Performance of different papaya cultivars under Terai Region of West Bengal. Horticultural J., 18(1): 13-16. 